\title{
TA'AWUN MEMBANGUN MASYARAKAT YANG BERDAYA : PEMBERDAYAAN MINYAK JELANTAH MENJADI SABUN CUCI TANGAN DI RT 03 / RW 04 KELURAHAN DUKUH SUTOREJO, KECAMATAN MULYOREJO, SURABAYA
}

\author{
Mahmud Muhsinin ${ }^{1}$, Tutut Putri Rahayu ${ }^{2}$ \\ Universitas Muhammadiyah Surabaya \\ muhsinin@fai.um-surabaya.ac.id'1 , tututputri29@gmail.com²
}

Submitted : 5 Oktober 2021 Accepted: 24 Desember 2021

Published : 31 Desember 2021

\begin{abstract}
Abstrak Program pengabdian merupakan kegiatan manusiawi yang dapat dilakukan oleh semua orang. Tidak memandang usia, baik yang sudah lanjut usia maupun yang masih muda. Dalam pengabdian banyak sekali hal ilmu serta pengalaman yang dapat diberikan dan ditularkan kepada sesama manusia dan masyarakat. Dari berbagai jurusan perkuliahan yang dapat diambil manfaat dalam teori maupun manfaat yang dapat di terapkan di masyarakat. Metode program malalui 3 tahapan, yaitu pertama tahap observasi, kedua tahap pendekatan sosial dan ketiga tahap pelaksanaan program. Pelaksanaan program juga dilakukan dalam 3 tahapan, yaitu : pertama perencanaan, kedua pelaksanaan dan ketiga evaluasi. Kesimpulan program kegiatan pengabdian masyarakat ini sangat diharapkan oleh warga. Kegiatan pelatihan dan sosialisasipembuatan sabun cuci tangan dari minyak jelantah mendapatkan perhatian yang serius dari perangkat desa. Sebagaimana disampaikan oleh ketua RT pak Wafiq al Muiz bahwa warga mengharapkan ada pelatihan kembali terkait pembuatan sabun tersebut dan berharap pembuatannya bisa dilakukan dalam skala besar.
\end{abstract}

Kata kunci : Minyak jelantah, sabun cuci tangan, masyarakat berdaya, pengabdian masyarakat 


\section{PENDAHULUAN}

Masa pandemi covid 19 masih berlangsung hingga saat ini. Dampak negatif yang dirasakan masyarakat sangat banyak, semua bidang terdampak pandemi covid 19. Sehingga prilaku masyarakat juga berubah dengan adanya covid 19 ini. Perubahan perilaku pada masyarakat dengan mengikuti anjuran pemerintah. Mulai dari mencuci tangan setelah beraktifitas diluar rumah, sehingga banyak ditemukan tempat kotak air dan sabun cuci tangan di depan rumah. Perilaku lainnya berupa memakai masker 2 embag beraktifitas diluar meskipun keluar tidak begitu jauh. Dan masih banyak lagi perubahan perilaku masyarakat setelah adanya wabah covid 19 ini.

Di sektor ekonomi Covid-19 memberikan dampak yang luar biasa, masyarakat dengan ekonomi bawah sangat merasakan dampak Covid-19 ini. Banyak pengusaha UMKM (Usaha Mikro, Kecil dan Menengah) yang melakukan perubahan dalam hal marketing, distribusi barang dan proses produksi untuk menyesuaikan dengan kondisi pendemi covid-19 ini. Hal itu dilakukan dalam rangka agar bisa tetap bertahan ditengah kesulitan ekonomi masa pandemi (Awali \& Rohmah, 2020 ; Budiarto, 2020).

Peran media sosial yang menyebar berita covid-19 secara berulang-ulang, berdampak sangat besar di masyarakat. Menimbulkan kesadaran di masyarakat bahwa virus ini sangat berbahaya. Keresahan masyarakat terhadap virus ini menjadikan perilaku masyarakat berubah. Berita covid-19 yang selalu terupdate membuat perubahan perilaku ini nampak pada masyarakat. Dalam hal ini masyarakat memiliki pola pikir yang baik menuruti anjuran pemerintah, mulai dari mencuci tangan setelah beraktifitas diluar rumah, terlihat banyak kotak air dan sabun cuci tangan di depan rumah. Selain hal itu masyarakat juga memakai masker 2 embag beraktifitas diluar meskipun keluar tidak begitu jauh. Jadi, dalam pemberitaan covid19 di media sosial memiliki dampak psikologis dan perilaku yang positif dan negatif (Sari, 2020).

Pandemi covid-19 berdampak negatif terhadap masyarakat di berbagai sektor atau bidang. Semua itu perlu ada solusi penanganannya dari komunitas 
kampus. Mahasiswa memiliki tugas untuk bisa mengurangi dampak negatif dari pandemi covid-19 ini. Oleh karena itu universitas muhammadiyah surabaya melakukan gerakan Back to Village. Gerakan kembali ke desa untuk membangun masyarakat dari dampak negatif pandemi covid-19.

Dampak negatif dari wabah covid-19 ini juga terjadi di Surabaya. Perubahan perilaku masyarakat juga terjadi di Surabaya. Timbulnya kecemasan di masyarakat akibat wabah covid-19, bahkan timbul kecemasan yang berlebihan. Hal ini terjadi karena dampak dari wabah covid-19 berupa ekonomi yang menurun, kesehatan yang menghawatirkan, pemberlakuan karantina, seruan untuk di rumah saja dan lainnya menjadikan masyarakat cemas dan jenuh dengan kondisi tersebut (Irda Sari, 2020). Untuk menghilangkan kecemasan tersebut masyarakat kemudian bersikap tidak mengindahkan pemberlakuan PPKM dan protokol kesehatan.

Gerakan Back to Village yang digalakkan Universitas Muhammadiyah Surabaya merupakan gerakan untuk membantu masyarakat Surabaya menangani dampak-dampak negatif wabah covid-19. Program ini merupakan program pengabdian masyarakat dari Universitas Muhammadiyah Surabaya. Program pengabdian masyarakat ini melibatkan mahasiswa dan dosen, dimana dosen ini bertindak sebagai pembimbing lapangan. Mahasiswa di bentuk berkelompok dengan satu dosen pembimbing lapangan. Masingmasing kelompok akan membuat program pengabdian masyarakat sesuai dengan kebutuhan dari lokasinya. Lokasi pelaksanaan pengabdian masyarakat di Kecamatan Mulyorejo, kelurahan Dukuh Mulyorejo, RW 04 RT 03 Kota Surabaya.

\section{METODE PELAKSANAAN}

Tahapan pelaksanaan program ini melalui 3 tahapan :

$$
\text { Pertama tahap observasi. }
$$

Pengamatan dan menggali informasi lewat wawancara merupakan cara yang dilakukan pada tahapan ini. Berdasarkan hasil observasi di RT 03 RW 04 Kelurahan Dukuh Mulyorejo, Kecamatan Mulyorejo, Kota Surabaya, bahwa banyak warga yang tidak memperhatikan protokol kesehatan, 
berkerumunan dan tidak memakai masker.

Kedua tahap pendekatan. Melakukan komunikasi dan pendekatan sosial dengan warga setempat. Diharapkan dengan cara ini mahasis wa dan civitas akademik dapat akrab dan menjalin komunikasi yang baik dengan warga setempat. Sebagaimana yang disampaikan oleh Farley, pendekatan sosial berdampak pada perubahan sosial akibat dari perubahan pola perilaku, hubungan sosial, 4embaga dan struktur sosial pada waktu tertentu. Perubahan sosial sendiri dikatakan sebagai perubahan yang terjadi pada kehidupan manusia yang diterim, berorientasi pada perubahan kondisi geografis kebudayaan materiil, komposisi penduduk, ideology maupun difusi dalam pertemuanpertemuan sesuatu yang baru ditemui (Indraddin \& Irwan, 2016).

Tahap pendekatan, dilakukan lewat struktur masyarakat berupa perangkat desa. Perizinan kepada kepada perangkat desa yaitu ketua RT 03 bapak M. Wafiq Al Muiz dan Ketua RW 04 Bapak Khoirul Anam.
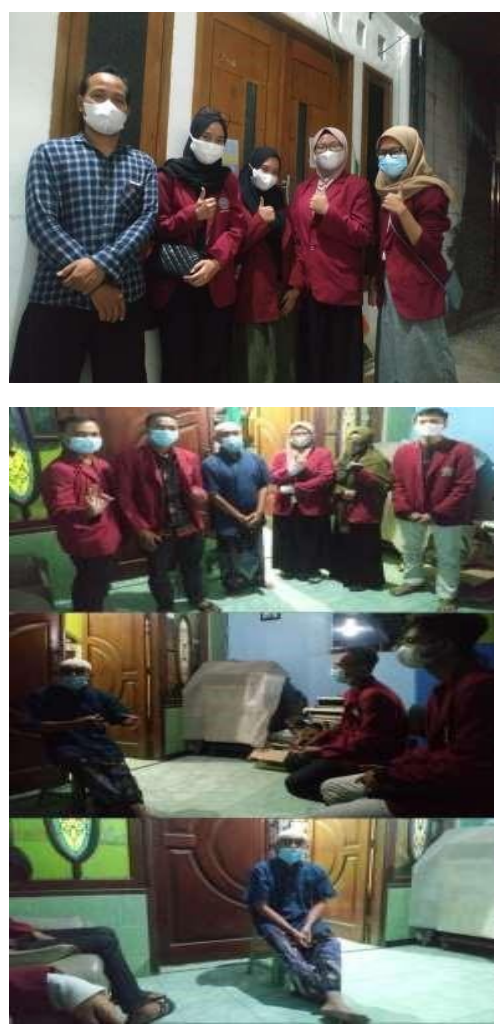

Gambar 1 Pertemuan dengan ketua RT 03 Bpk. M. Wafiq Al Muiz dan Pertemuan dengan ketua RW 04 Bpk. Khoirul Anam

Ketiga tahap pelaksanaan. Tahapan ini meliputi 3 hal yaitu : perencanaan, pelaksanaan dan evaluasi. Perencanaan merupakan tahap persiapan dan penyusunan program kegiatan, termasuk pembagian kerja. Selanjuatnya pelaksanaan merupakan proses pelaksanaan program kegiatan. Kemudian evaluasi dilakukan dua kali yaitu pertengahan dan akhir kegiatan.

Perencanaan dilakukan dengan melihat kebutuhan dari warga setempat. 
Program disesuaikan dengan hasil observasi dan pendekatan sosial yang telah dilakukan sebelumnya. Hasil penyusunan program berupa proposal kegiatan diserahkan kepada Ketua RT dan RW setempat. Hal ini dimaksudkan agar hubungan antara mahasiswa dan warga setempat lebih harmonis dan program-program pengabdian masyarakat dapat diterima dan terlaksana dengan baik.

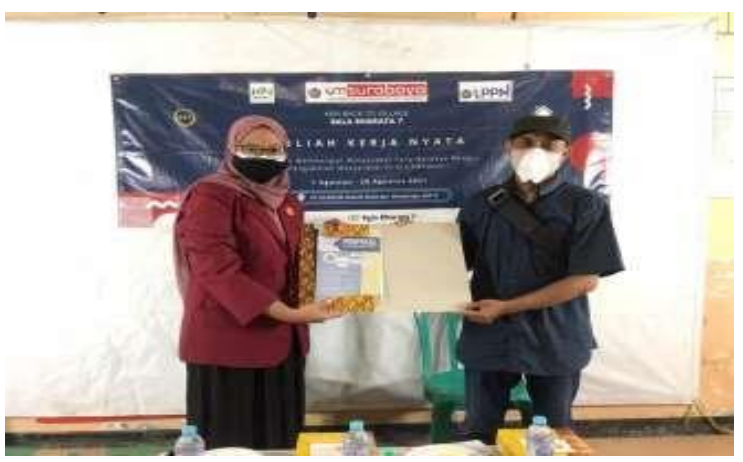

Gambar 2 Penyerahan Proposal Kegiatan kepada perangkat desa setempat

\section{PEMBAHASAN}

Program pengabdian merupakan kegiatan manusiawi yang dapat dilakukan oleh semua orang. Tidak memandang usia, baik yang sudah lanjut usia maupun yang masih muda. Dalam pengabdian banyak sekali hal ilmu serta pengalaman yang dapat diberikan dan ditularkan kepada sesama manusia dan masyarakat. Dari berbagai jurusan perkuliahan yang dapat diambil manfaat dalam teori maupun manfaat yang dapat di terapkan di masyarakat.

$$
\text { Program kegiatan yang }
$$

dikembangkan meliputi 3 hal, yaitu : edukasi protokol kesehatan, mengembangkan potensi-potensi yang ada menjadi hal-hal yang berguna, dan melakukan kegiatan perayaan HUT RI sesuai protokol kesehatan agar mengurangi rasa jenuh dan kecemasan di masyarakat.

Program edukasi kesehatan meliputi kegiatan : Pertama, penyemprotan cairan desinfektan ke rumah-rumah warga secara menyeluruh. Setiap rumah warga di semprot cairan desinfektan tanpa terkecuali. Kawasan yang disemprot semua wilayah RT 03 yang berjumlah ada $200 \mathrm{KK} / \mathrm{rumah}$ dan kos rumah tangga.
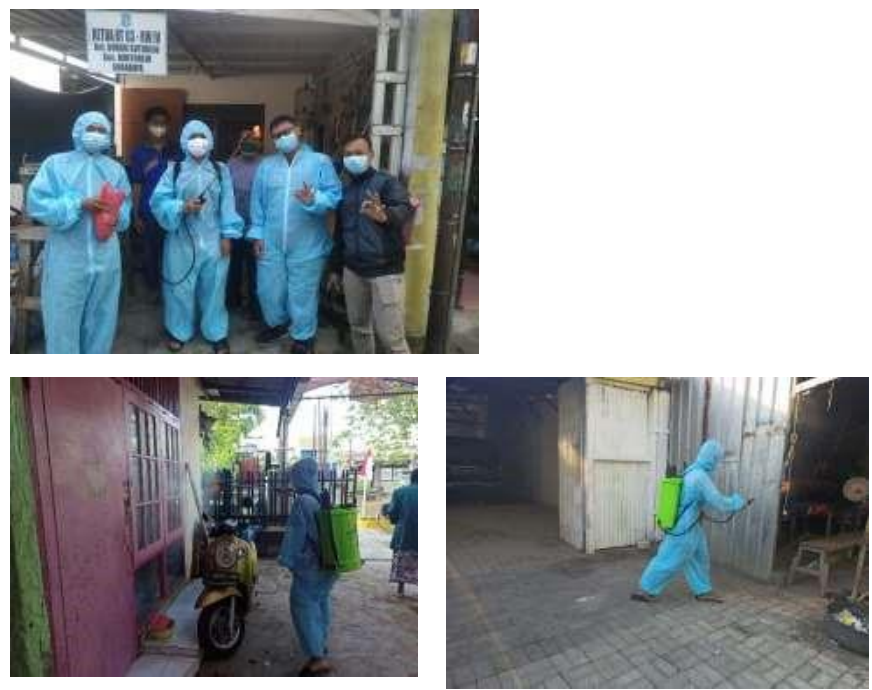

Gambar 3 Penyemprotan desinfektan 
Penyemprotan desinfektan ni dilakukan pada hari Ahad pukul 07.00 WIB pagi hari. Mahasiswa pada saat melakukan penyemprotan menggunakan APD lengkap dengan membawa mesin penyemprot desinfektan. Diharapkan dengan program ini secara rutin dan terus-menerus dapat menurunkan angka diagnosa positif covid di kelurahan Dukuh Sutorejo.

Program edukasi kesehatan yang kedua berupa penyebaran video edukasi kesehatan dan penyebaran poster edukasi kesehatan. Video edukasi kesehatan di share ke grup wa warga. Sedangkan poster edukasi kesehatan ditepatkan di warung makan, Giras, dan toko-toko.
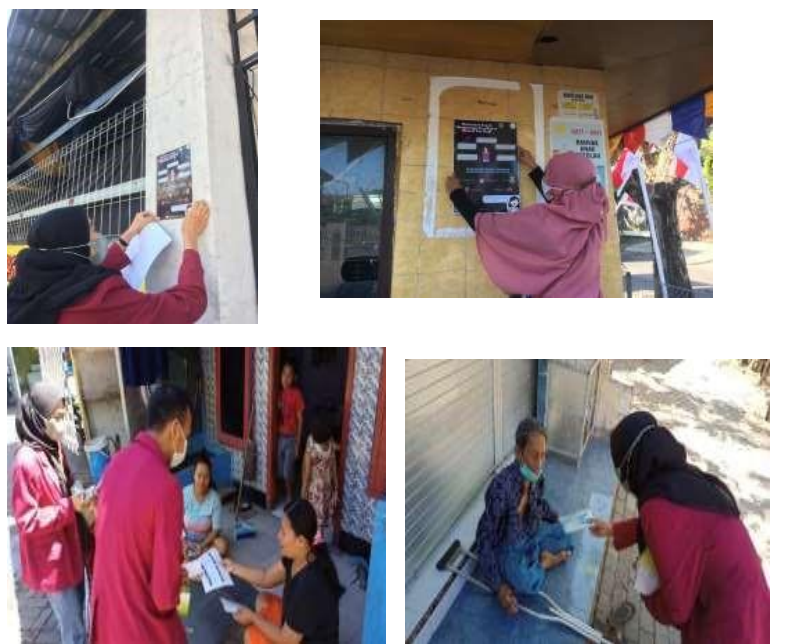

Gambar 4 Penyebaran posteredukasi kesehatan dan pembagian masker
Kegiatan lainnya berkaitan dengan edukasi kesehatan adalah pembagian masker ke warga, diharapkan dengan semua kegiatan edukasi kesehatan ini, masyarakat menjadi lebih memahami terkait protokol kesehatan dan pentingnya menjaga diri dan lingkungan dari virus covid 19.

Program kedua berkaitan dengan pengembangan potensi-potensi yang ada menjadi hal-hal yang berguna. Program ini terdiri dari 2 kegiatan yaitu; penanaman sayuran dan buah di lahan taman yang tidak terawat, dan pembuatan sabun cuci tangan dari minyak jelantah.

Kegiatan penanaman sayuran dan buah di lahan taman yang tidak terawat, dengan harapan warga dapat merawat tanaman berupa sayur dan buah ini. Pemilihan tanaman sayur dan buah dengan tujuan agar bisa dimanfaatkan dan dikonsumsi oleh warga. Sehingga dengan menanam tanaman toga dan sayuran seperti tomat, terung, lombok, sereh dan lainnya, warga terutama ibu rumah tangga bisa berhemat dan mengurangi jumlah pengeluaran tiap harinya. 

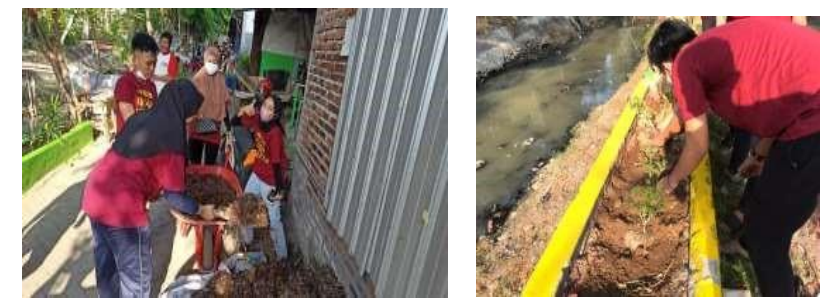

Gambar 5 Penanaman sayur-sayuran di lahan depan rumah warga

Kegiatan pembuatan sabun cuci tangan dari minyak jelantah merupakan kegiatan sosialisasi dan pelatihan kepada warga. Sosialisasi pengolahan limbah minyak jelantah diubah menjadi sabun cuci tangan berupa sabun batang dan sabun cair sangat diperlukan pada saat pandemi seperti ini, kita membiasakan diri untuk mencuci dan membersihkan tangan dalam rangka mencegah penularan covid 19.

Kegiatan sosialisasi dan pelatihan pembuatan sabun cuci tangan dari minyak jelantah dilakukan secara offline dan online. Pelatihan dilaksanakan secara offline dengan mengundang beberapa warga dalam rangka menghindari kerumunan warga. Sedangkan sosialisasi dilakukan dengan menyebar video cara pembuatan sabun cuci tangan dari minyak jelantah lewat sosial media warga.
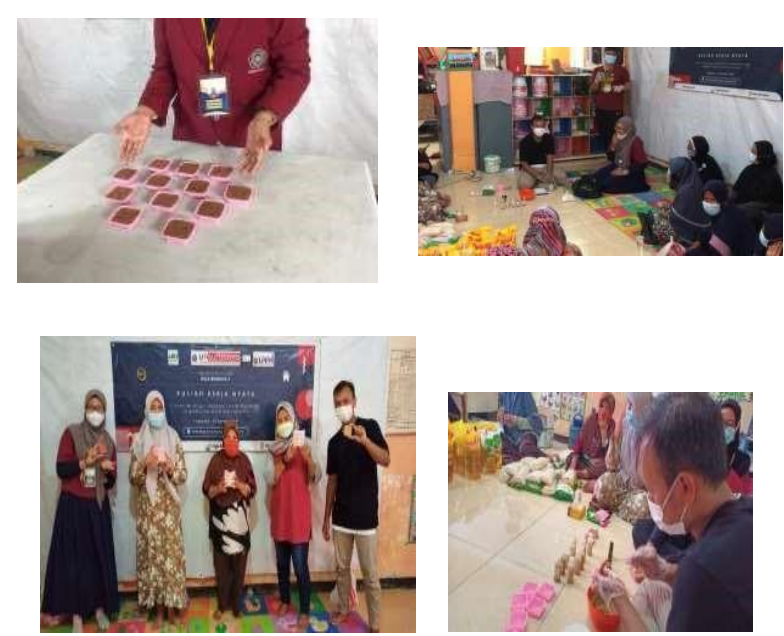

Gambar 6 Pelatihan pembuatan sabun cuci tangan dari minyak jelantah

Lewat program ini diharapkan warga dapat memanfaatkan potensipotensi yang ada di lingkungan sekitar seperti lahan tanah dan minyak bekas menjadi hal-hal yang berguna.

Program ketiga berkaitan dengan mengurai rasa kejenuhan dan kecemasan warga akibat dampak pandemi covid-19. Kegiatannya dengan melakukan perayaan HUT RI sesuai protokol kesehatan. Perayaan hari kemerdekaan Indonesia sering dirayakan warga dengan mengadakan lomba untuk warga. Perlombaan ini dilaksanakan di lapangan dan biasanya akan dihadiri oleh seluruh warga. Di masa pandemi seperti sekarang, hal tersebut tidak diperkenankan oleh pemerintah sebab bisa memicu penyebaran covid-19. Maka dari para mahasiswa berinisatif 
mengadakan lomba secara daring atau online.

Mekanisme pelaksanaan lomba sebagai berikut : pertama sosialisasi lomba 17 Agustus secara daring/online melalui grup wa warga.
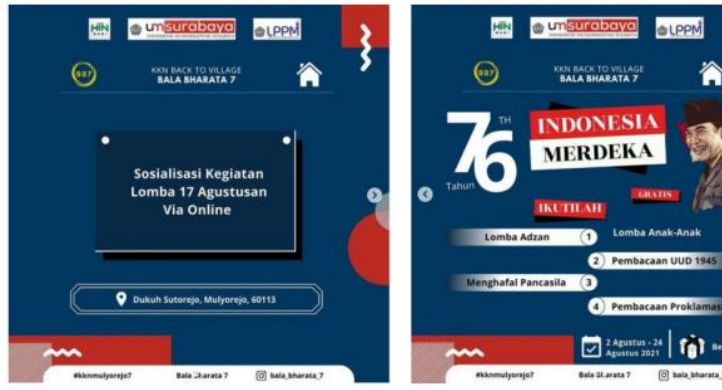

Gambar 7 Penyebaran famplet di grup wa warga

Tahap selanjutnya menerima video peserta lomba. Panitia menerima video peserta lomba yang dikirim lewat wa. Pengiriman video diberi waktu dari tanggal 2 sampai 24 agustus. Pembagian hadiah dilakukan pada tanggal 28 agustus.
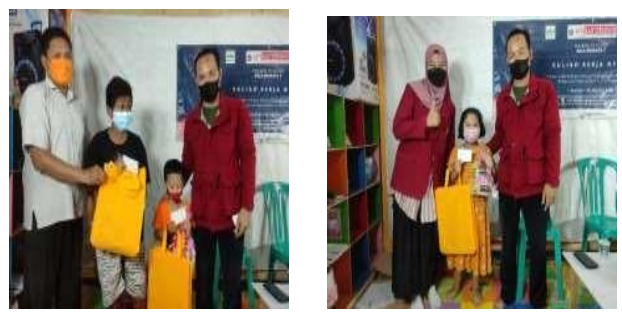

Gambar 8 Pembagian Hadiah lomba perayaan hari kemerdekaan

Kegiatan perayaan kemerdekaan diharapkan bisa menjadi hiburan bagi warga yang merasa jenuh dengan kondisi pandemi selama ini. Secara psikologi adanya hiburan ini menghilangkan rasa kecemasan yang selama ini dirasakan warga terkait suasana pandemi.

\section{HASIL PELAKSANAAN}

Hasil pelaksanaan kegiatan pengabdian masyarakat ini terdiri dari 2 hal pertama terkait pelaksanaan program dan kedua terkait hasil evaluasi program.

Secara umum program pengabdian masyarakat dapat terlaksana dengan baik dan mendapat dukungan dari perangkat desa dan warga. Selama pelaksanaan kegiatan, keterlibatan warga untuk mengikuti kegiatan sangat antusias. Setiap kegiatan yang berjalan selalu diikuti warga dan didukung oleh perangkat desa. Sehingga kami sangat berterima kasih atas sambutan dan dukungan dari warga setempat terhadap kegiatan-kegiatan yang kami lakukan.

Hasil evaluasi program, bahwa kegiatan pengabdian masyarakat ini sangat diharapkan oleh warga. Kegiatan pelatihan dan sosialisasi pembuatan sabun cuci tangan dari minyak jelantah mendapatkan perhatian yang serius dari perangkat desa. Sebagaimana disampaikan oleh ketua RT pak Wafiq al Muiz bahwa warga mengharapkan ada pelatihan kembali terkait pembuatan sabun tersebut dan berharap 
pembuatannya bisa dilakukan dalam skala besar. Terkait permohonan dari pak RT ini, kami menampung dan menyampaikan ke pihak LPPM (Lembaga Penelitian Pengabdian Masyarakat) UM Surabaya. Produk sabun tersebut masih akan dilakukan uji laboratorium untuk kemudian bisa di buat dalam skala besar.

\section{KESIMPULAN}

Pelaksanaan kegiatan pengabdian masyarakat dilakukan meliputi pelaksanaan program dan kedua terkait hasil evaluasi program. Pelaksanaan program terdiri dari edukasi protokol kesehatan. Secara umum program pengabdian masyarakat dapat terlaksana dengan baik dan mendapat dukungan dari perangkat desa dan warga. Selama

\section{DAFTAR PUSTAKA}

Awali, H., \& Rohmah, F. (2020). Di Tengah Dampak Covid-19. Jurnal Ekonomi Dan Bisnis Islam, 2(1).

Budiarto, B. (2020). Ketahanan Sektor Informal Pada Masa Pandemi Covid19 Di Kabupaten Sidoarjo. Journal of Economics Development Issues,

https://doi.org/10.33005/jedi.v3i2.

67

Indraddin, \& Irwan. (2016). Strategi Dan Perubahan Sosial. In Sosiologi.

Irda Sari. (2020). ANALISIS DAMPAK

PANDEMI COVID- 19 TERHADAP KECEMASAN MASYARAKAT : LITERATURE REVIEW. Bina Generasi: Jurnal Kesehatan, 12(1).

https://doi.org/10.35907/bgjk.v12i

1.161

Sari, F. L. (2020). DAMPAK PEMBERITAAN COVID19 DI MEDIA SOSIAL TERHADAP PERILAKU MASYARAKAT DI DUSUN KEMUNING

KELURAHAN LIRBOYO KOTA KEDIRI. MEDIAKITA, 4(1). https://doi.org/10.30762/mediakita. v4i1.2449 